\title{
Influence of Host and Viral Factors on Patients with Chronic Hepatitis C Virus Genotype 6 Treated with Pegylated Interferon and Ribavirin: A Systematic Review and Meta-Analysis
}

\author{
Vo Duy Thonga, ${ }^{\text {a d }}$ Kittiyod Poovorawan ${ }^{c}$ Pisit Tangkijvanich ${ }^{b}$ \\ Rujipat Wasitthankasem $^{\text {a }}$ Sompong Vongpunsawad ${ }^{a}$ Yong Poovorawan $^{\text {a }}$ \\ ${ }^{a}$ Center of Excellence in Clinical Virology and ${ }^{b}$ Research Unit of Hepatitis and Liver Cancer, Department of \\ Biochemistry, Faculty of Medicine, Chulalongkorn University, and ${ }^{\mathrm{b}}$ Department of Clinical Tropical Medicine, \\ Faculty of Tropical Medicine, Mahidol University, Bangkok, Thailand; ${ }^{\mathrm{d}}$ Department of Internal Medicine, Faculty of \\ Medicine, University of Medicine and Pharmacy, Ho Chi Minh City, Vietnam
}

\section{Key Words}

Genotype 6 - Hepatitis C virus · Host factors - Meta-analysis . Pegylated interferon · Ribavirin · Viral factors

\section{Abstract}

Objectives: We conducted a systematic review and metaanalysis of the influence of host and viral factors on the sustained virologic response (SVR) in hepatitis $C$ virus genotype 6 (HCV-6) patients treated with pegylated interferon (PEGIFN) and ribavirin (RBV). Methods: Data were retrieved from Medline, Embase, PubMed and the Cochrane Library for 'genotype 6' studies published up to December 2014 and for abstracts from international scientific meetings. Inclusion criteria were efficacy of PEG-IFN+RBV based on SVR, 24or 48-week therapy and treatment-naïve patients. Patients with hepatitis B, D and E and HIV coinfection or another concurrent liver disease were excluded. Pooled standard difference, odds ratio and confidence intervals $(\mathrm{Cls})$ were calculated using a random-effect model with STATA 11. Results: Fourteen studies were included in the meta-analysis. The pooled SVR rate was $80 \%\left(95 \% \mathrm{Cl}: 0.78-0.83, \mathrm{p}<0.0001 ; I^{2}=\right.$ 71.2\%). SVR of the PEG-IFN+RBV-treated HCV-6 patients was markedly higher than that of HCV-1 patients ( $80.1 \mathrm{vs.} 55.3 \%$ ). The SVR rate was significantly higher for the 48- than the 24week treatment, but not different among HCV-infected patients with rs 12979860 and ss 469415590 polymorphisms of the ILFN4 gene ( $80.6 \%$ CC vs. $66.7 \%$ non-CC, $p=0.593 ; 81.1 \%$ $\Pi / T T$ vs. $60 \%$ non- $T$ T/TT, $p=0.288)$. Gender and type of PEG-IFN did not affect SVR rates. Conclusions: Treatment outcomes for HCV- 6 patients are superior to those for HCV1 patients and comparable to those of HCV-2 and HCV-3 patients, especially at 48 weeks. The level of fibrosis affects treatment outcome, but SVR rates are not significantly different between genders. IL28B and IFNL4 polymorphisms are not significantly associated with HCV- 6 treatment outcome.

(c) 2016 S. Karger AG, Basel

\section{Introduction}

Hepatitis $\mathrm{C}$ virus (HCV) is an important public health problem with more than 160 million cases of chronic infection worldwide [1]. HCV infection commonly progresses to liver fibrosis, cirrhosis and hepatocellular car-

\section{KARGER 125}

(c) 2016 S. Karger AG, Base

$0300-5526 / 16 / 0586-0373 \$ 39.50 / 0$

E-Mail karger@karger.com

www.karger.com/int
Prof. Yong Poovorawan, MD

Center of Excellence in Clinical Virology, Faculty of Medicine, Chulalongkorn University Rama IV Road

Bangkok 10330 (Thailand)

E-Mail Yong.P@chula.ac.th 
cinoma, and related mortality is predicted to increase over the next two decades [2]. Genotype 1 (HCV-1) is found globally, especially in developed regions, such as America and Europe. HCV -3 and -6 are predominantly detected in Asian countries, which have a high prevalence of HCV [3].

Various factors can be effectively used to identify treatment responses in HCV patients. The standard treatment for $\mathrm{HCV}$ is a combination of pegylated interferon (PEGIFN) and ribavirin (RBV) with a 24- to 48-week regimen, depending on the viral genotype of infected individuals [4-6]. Previous studies have reported that treatment outcomes of HCV-6 are closer to those of HCV-2 and HCV3 [7-9], but patients infected with HCV-6 respond better to therapy than those with HCV-1 [3], defined as sustained virologic response (SVR). Several host factors, including age, sex, race and the level of fibrosis, additionally influence treatment outcome. Single nucleotide polymorphisms on chromosome 19 within or near the interleukin-28B gene (IL28B encoding interferon $\lambda$-3) represent one of the strongest baseline predictors of SVR in HCV treatment. Recent studies have additionally shown that the IFN- $\lambda-4$ (IFNL4) gene polymorphisms are in high linkage disequilibrium with those near IL28B and more strongly associated with spontaneous or treatmentinduced HCV clearance than IL28B genotypes.

While advances in HCV therapy continue to evolve rapidly with the development of potent direct-acting antiviral agents [10], limited data availability has prevented general recommendations for HCV-6 therapy. PEGIFN $+\mathrm{RBV}$ combination therapy continues to be a predominant option in resource-limited settings due to the high costs associated with new agents. To date, only one study reported on the influence of host and viral factors in HCV-4 [11]. Moreover, this treatment option remains elusive for patients in developing countries, such as Asia, where HCV-6 infection is high and funding for medications is inadequate. The current study aims to provide a systematic review and meta-analysis of the influence of host and viral factors on virologic response in HCV-6 patients treated with PEG-IFN+RBV.

\section{Materials and Methods}

Data Sources and Search Strategy

This systematic review was conducted according to PRISMA guidelines [12]. PubMed, Embase, Medline and the Cochrane Library were used for comprehensive literature searches. We searched the databases for the following term: genotype 6 . The search was conducted for studies published from inception to De- cember 2014 and also included a manual search of abstracts using the term genotype 6 from annual international scientific meetings in the areas of liver disease. To ensure maximum sensitivity of our search strategy, we kept the search string as simple as possible, using only key words without filters. Search and study selection were performed without language limitations. We reviewed the bibliographies of relevant published articles for inclusion in our study. References concerning previous meta-analyses were additionally explored for eligibility.

\section{Inclusion and Exclusion Criteria}

Data were included based on the following criteria: (i) treatment-naive patients, (ii) assessment of the efficacy of PEGIFN+RBV therapy based on SVR, which was defined as undetectable HCV-RNA at least 24 weeks after the end of treatment, (iii) course of treatment (24 or/and 48 weeks), and (iv) reports in English. We excluded studies comprising patients with hepatitis B, D and $\mathrm{E}$ or HIV coinfection and those with other concurrent liver diseases. Studies were additionally excluded if insufficient data were available for pooling. Two of the authors independently reviewed the articles, and discrepancies were reviewed by another author and resolved by consensus.

\section{Data Extraction}

Information extracted from published material included study data (author, publication year and status, country of origin, continent, study design, total sample size, HCV genotype and type of PEG-IFN used), demographic data on study participants (age, sex and ethnicity) and treatment outcomes (number of patients who achieved or failed to achieve SVR). Data on treatment characteristics were additionally collected, including IL28B and IFNL4 polymorphisms, duration of treatment ( 48 vs. 24 weeks), baseline HCV-RNA levels and stage of liver fibrosis/cirrhosis.

\section{Statistical Analysis}

Pooled standard differences in means (overall SVR rates) and 95\% confidence intervals (CIs) were calculated for each group using a random-effect model and inverse variance method [13]. Heterogeneity was tested with $\chi^{2}$ test-based Cochran's Q statistics with $p$ values up to 0.05 , and the degree of heterogeneity quantified using the $I^{2}$ statistic representing the percentage of total variability across studies due to heterogeneity. $I^{2}$ values of 25,50 and $75 \%$ corresponded to low, moderate and high degrees of heterogeneity, respectively. Univariate and multivariate random-effect meta-regression on study level characteristics was performed to explain any observed heterogeneity in primary outcomes and identify associated patient level factors $[13,14]$. We quantified publication bias using Egger's regression model. All analyses were performed with STATA 11 (Stata Corporation, College Station, Tex., USA) [15, 16].

\section{Results}

\section{Study Selection}

In total, 207 articles relevant to the HCV-6 were initially identified from our searches. The modified process employed for study search and selection is summarized in figure 1. After the titles were screened and abstracts 
Fig. 1. Flow diagram of study inclusion criteria for meta-analysis.

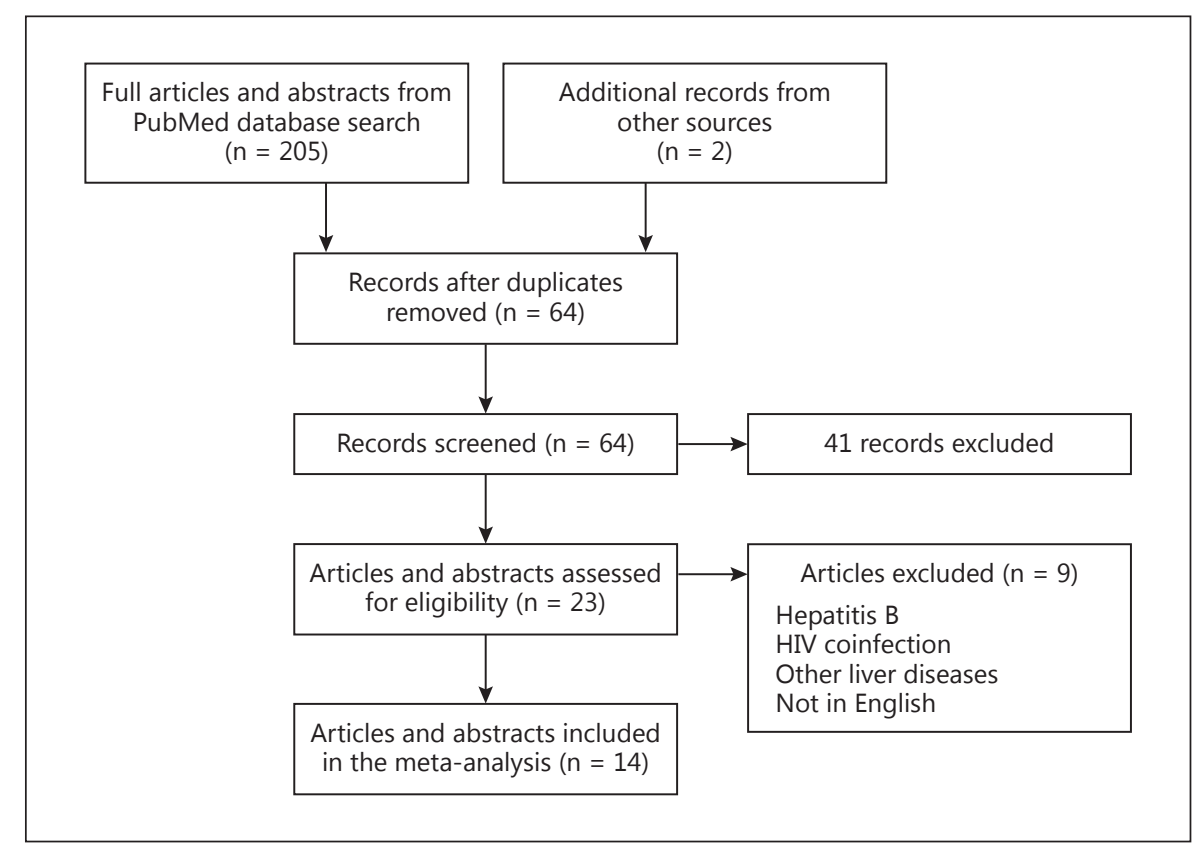

read, 193 studies were removed based on exclusion criteria and 14 potentially eligible articles included [17-30]. Among these studies, some studies were only included on the treatment efficacy of PEG-IFN+RBV for HCV-6 in a previous study [31]. More new published studies were added to our study to investigate the influence of host and viral factors on HCV-6 treatment response to improve data analysis.

\section{Clinical Study and Patient Characteristics}

Characteristics of the included studies are presented in table 1 . The pooled number of HCV-6 patients was 1,176 and study sizes ranged from 12 to 70 , except for one study, which included 242 patients. Six studies evaluated patients with $\mathrm{HCV}-1$ and -6 , and 3 evaluated patients with HCV $-1,-2,-3$ and -6 . Seven of the studies evaluated HCV6 only. The majority of studies $(n=11)$ were nonrandomized clinical trials (non-RCT; 2 RCT) with predominantly male patients. Mean age ranged from 19 to 50 years. In all studies, patients underwent combination treatment with PEG-IFN+RBV for 48 weeks; only 5 studies evaluated the effects of therapy for 24 weeks. The funnel plot was symmetrical and Egger's regression for publication bias was not statistically significant $(\mathrm{p}=0.912$; fig. 2$)$.

\section{Overall SVR Rates}

Thirteen trials reported SVR data from a total of 891 HCV-6 patients. SVR to PEG-IFN plus weight-based
RBV therapy in HCV patients ranged from 39 to $92.8 \%$. In influence analysis, the pooled SVR rate for all studies was $80 \%$ (95\% CI: $0.78-0.83$; $\mathrm{p}<0.0001 ; I^{2}=71.2 \%$; fig. 3 ).

Upon comparing RCT versus non-RCT, we observed a pooled SVR rate of 70\% (95\% CI: $0.64-0.77)$ in 2 RCTs $[20,27]$, compared with $83 \%$ (95\% CI: $0.79-0.86$ ) in 11 non-RCTs. This finding was statistically significant ( $\mathrm{p}=$ 0.032 ). Heterogeneity was observed in both subgroups $\left(I^{2}=72.1 \%\right.$ for non-RCT; $I^{2}=67.1 \%$ for RCT $)$.

\section{SVR Rates in Relation to Host and Viral Factors}

Male versus Female Patients

In 11 of the 14 studies with 891 HCV-6 patients, gender was reported for 537 patients, 320 (60\%) males and 217 (40\%) females, which included information on the influence of sex on SVR. The SVR rate was $72 \%$ in males (95\% CI: $0.62-0.87$ ) and 73\% in females (95\% CI: 0.61$0.89)$. Notably, no significant differences in SVR were evident between males and females with an odds ratio (OR) of 0.81 (95\% CI: $0.71-1.12, \mathrm{p}=0.71)$. Weak heterogeneity was observed in our model $\left(I^{2}=2 \%, \mathrm{p}=0.42\right)$.

\section{IL28B and IFNL4 Polymorphisms}

Two studies involving 102 patients assessed SVR in relation to $I L 28 B$ polymorphisms while 1 study focused on IFNL4 polymorphisms $[23,29]$. Among the 2 studies on $I L 28 B$ polymorphisms, 1 study investigating 60 HCV-6 patients [52 (90\%) TT and 8 (10\%) GT/GG] as- 
Table 1. Characteristics of studies included in the meta-analysis of HCV-6 patients treated with PEG-IFN+RBV

\begin{tabular}{|c|c|c|c|c|c|c|c|c|c|}
\hline Study & $\begin{array}{l}\text { Study design/ } \\
\text { publication type }\end{array}$ & $\begin{array}{l}\text { Country } \\
\text { (population) }\end{array}$ & $\begin{array}{l}\text { Treatment regime } \\
(\mathrm{PEG}-\mathrm{IFN}+\mathrm{RBV})\end{array}$ & $\begin{array}{l}\text { Geno- } \\
\text { type }\end{array}$ & $\begin{array}{l}\text { Treatment, } \\
\text { weeks }\end{array}$ & $\begin{array}{l}\text { HCV-6 } \\
\text { patients }\end{array}$ & $\begin{array}{l}\text { Males, } \\
\text { n (\%) }\end{array}$ & $\begin{array}{l}\text { Age, } \\
\text { years }\end{array}$ & $\begin{array}{l}\text { SVR, } \\
\text { n (\%) }\end{array}$ \\
\hline $\begin{array}{l}\text { Nguyen et al. [24], } \\
2008\end{array}$ & Non-RCT & $\begin{array}{l}\text { US (Asian } \\
\text { American) }\end{array}$ & $\begin{array}{l}\text { PEG-IFN } \alpha-2 a \\
\text { PEG-IFN } \alpha-2 b\end{array}$ & $\begin{array}{l}6 \\
6\end{array}$ & $\begin{array}{l}24 \\
48\end{array}$ & $\begin{array}{l}23 \\
12\end{array}$ & $\begin{array}{l}16(69.6) \\
7(58.3)\end{array}$ & $\begin{array}{l}49 \pm 10 \\
50 \pm 10\end{array}$ & $\begin{array}{l}9(39) \\
9(75)\end{array}$ \\
\hline $\begin{array}{l}\text { Fung et al. [27], } \\
2008\end{array}$ & Non-RCT & $\begin{array}{l}\text { Hong Kong } \\
\text { (Chinese) }\end{array}$ & $\begin{array}{l}\text { PEG-IFN } \alpha-2 a \\
\text { PEG-IFN } \alpha-2 b\end{array}$ & $\begin{array}{l}1 \\
6\end{array}$ & $\begin{array}{l}48 \\
48\end{array}$ & $\begin{array}{l}21 \\
21\end{array}$ & $\begin{array}{l}12(57) \\
11(52)\end{array}$ & $\begin{array}{l}52(30-63) \\
49.6(14-64)\end{array}$ & $\begin{array}{l}11(52) \\
18(86)\end{array}$ \\
\hline $\begin{array}{l}\text { Lam et al. [26], } \\
2010\end{array}$ & RCT & $\begin{array}{l}\text { US } \\
\text { (Asian } \\
\text { American) }\end{array}$ & $\begin{array}{l}\text { PEG-IFN } \alpha-2 a \\
\text { PEG-IFN } \alpha-2 a\end{array}$ & $\begin{array}{l}6 \\
6\end{array}$ & $\begin{array}{l}24 \\
48\end{array}$ & $\begin{array}{l}27 \\
33\end{array}$ & $\begin{array}{l}13(48) \\
15(46)\end{array}$ & $\begin{array}{l}49.6 \pm 12.4 \\
52.8 \pm 8.0\end{array}$ & $\begin{array}{l}19(70) \\
26(79)\end{array}$ \\
\hline $\begin{array}{l}\text { Nguyen et al. [30], } \\
2010^{\mathrm{a}}\end{array}$ & Non-RCT & $\begin{array}{l}\text { US } \\
\text { (Asian } \\
\text { American) }\end{array}$ & $\begin{array}{l}\text { PEG-IFN } a-2 a \\
\text { PEG-IFN } a-2 b \\
\text { PEG-IFN } a-2 b\end{array}$ & $\begin{array}{l}1 \\
6\end{array}$ & $\begin{array}{l}48 \\
24 \\
48\end{array}$ & $\begin{array}{l}70 \\
27 \\
34\end{array}$ & $\begin{array}{l}51(73) \\
15(56) \\
19(56)\end{array}$ & $\begin{array}{l}50 \pm 9.7 \\
49.4 \pm 12.0 \\
49.4 \pm 10.8\end{array}$ & $\begin{array}{l}25(49) \\
17(63)\end{array}$ \\
\hline $\begin{array}{l}\text { Tsang et al. [19], } \\
2010\end{array}$ & Non-RCT & $\begin{array}{l}\text { Hong Kong } \\
\text { (Chinese) }\end{array}$ & $\begin{array}{l}\text { PEG-IFN } \alpha-2 a \\
\text { PEG-IFN } \alpha-2 b\end{array}$ & $\begin{array}{l}1 \\
6\end{array}$ & $\begin{array}{l}48 \\
48\end{array}$ & $\begin{array}{l}70 \\
70\end{array}$ & $\begin{array}{l}44(63) \\
23(33)\end{array}$ & $\begin{array}{l}48(18-64) \\
50(28-75)\end{array}$ & $\begin{array}{l}40(57.1) \\
53(75.7)\end{array}$ \\
\hline $\begin{array}{l}\text { Zhou et al. [18], } \\
2011^{\mathrm{a}}\end{array}$ & $\begin{array}{l}\text { Non-RCT } \\
\text { full }\end{array}$ & $\begin{array}{l}\text { China } \\
\text { (Chinese) }\end{array}$ & $\begin{array}{l}\text { PEG-IFN } \alpha-2 a \\
\text { PEG-IFN } \alpha-2 b\end{array}$ & $\begin{array}{l}1 \\
6\end{array}$ & $\begin{array}{l}48 \\
24\end{array}$ & $\begin{array}{l}39 \\
22\end{array}$ & $\begin{array}{l}22(56.4) \\
14(63.6)\end{array}$ & $\begin{array}{l}15(38.5) \\
19(84.6)\end{array}$ & $\begin{array}{l}23(59.0) \\
18(81.8)\end{array}$ \\
\hline $\begin{array}{l}\text { Qing-Xian et al. } \\
{[28], 2011}\end{array}$ & $\begin{array}{l}\text { Non-RCT } \\
\text { abstract }\end{array}$ & $\begin{array}{l}\text { China } \\
\text { (Chinese) }\end{array}$ & PEG-IFN $a-2 b$ & 6 & 48 & 84 & NR & $\mathrm{NR}$ & $74(88.1)$ \\
\hline $\begin{array}{l}\text { Tangkijvanich } \\
\text { et al. }[21], 2012^{\text {a }}\end{array}$ & $\begin{array}{l}\text { Non-RCT } \\
\text { full }\end{array}$ & $\begin{array}{l}\text { Thailand } \\
\text { (Thai) }\end{array}$ & $\begin{array}{l}\text { PEG-IFN } \alpha-2 a \\
\text { PEG-IFN } \alpha-2 a\end{array}$ & $\begin{array}{l}1 \\
6\end{array}$ & $\begin{array}{l}48 \\
48\end{array}$ & $\begin{array}{l}16 \\
34\end{array}$ & $\begin{array}{l}9(56.3) \\
23(67.6)\end{array}$ & $\begin{array}{l}46.4 \pm 12.5 \\
41.2 \pm 8.4\end{array}$ & $\begin{array}{l}10(62.5) \\
26(76.5)\end{array}$ \\
\hline $\begin{array}{l}\text { Shao et al. [22], } \\
2012\end{array}$ & $\begin{array}{l}\text { Non-RCT } \\
\text { abstract }\end{array}$ & $\begin{array}{l}\text { China } \\
\text { (Chinese) }\end{array}$ & PEG-IFN $a-2 a$ & 6 & 48 & 28 & NR & $\mathrm{NR}$ & $26(92.8)$ \\
\hline $\begin{array}{l}\text { Mauss et al. [25], } \\
2012^{\mathrm{a}}\end{array}$ & $\begin{array}{l}\text { Non-RCT } \\
\text { full }\end{array}$ & $\begin{array}{l}\text { Germany } \\
\text { (Caucasian, } \\
\text { African, Asian, } \\
\text { Hispanic) }\end{array}$ & PEG-IFN $\alpha-2 a$ & 6 & 48 & 27 & $17(63)$ & $47(37-52)$ & $16(59)$ \\
\hline $\begin{array}{l}\text { Thu Thuy et al. } \\
{[20], 2012}\end{array}$ & $\begin{array}{l}\text { RCT } \\
\text { full }\end{array}$ & $\begin{array}{l}\text { Vietnam } \\
\text { (Vietnamese) }\end{array}$ & $\begin{array}{l}\text { PEG-IFN } \alpha-2 a \\
\text { PEG-IFN } \alpha-2 a\end{array}$ & $\begin{array}{l}6 \\
6\end{array}$ & $\begin{array}{l}24 \\
48\end{array}$ & $\begin{array}{l}35 \\
70\end{array}$ & $\begin{array}{l}22(62.9) \\
43(61.4)\end{array}$ & $\begin{array}{l}46.82 \pm 7.2 \\
48.57 \pm 8.4\end{array}$ & $\begin{array}{l}21(60) \\
50(71)\end{array}$ \\
\hline $\begin{array}{l}\text { Seto et al. [23], } \\
2013\end{array}$ & $\begin{array}{l}\text { Non-RCT } \\
\text { full }\end{array}$ & $\begin{array}{l}\text { Hong Kong } \\
\text { (Chinese) }\end{array}$ & PEG-IFN $a-2 b$ & 6 & 48 & 60 & $41(68.3)$ & $49(14-71)$ & 55 (91.7) \\
\hline $\begin{array}{l}\text { Qing-Xian et al. } \\
\text { [17], } 2013\end{array}$ & $\begin{array}{l}\text { RCT } \\
\text { abstract }\end{array}$ & $\begin{array}{l}\text { China } \\
\text { (Chinese) }\end{array}$ & $\begin{array}{l}\text { PEG-IFN } \alpha-2 a \\
\text { PEG-IFN } \alpha-2 a\end{array}$ & $\begin{array}{l}6 \\
6\end{array}$ & $\begin{array}{l}24 \\
48\end{array}$ & 242 (total) & $\begin{array}{l}\text { NR } \\
\text { NR }\end{array}$ & $\begin{array}{l}\text { NR } \\
\text { NR }\end{array}$ & $\begin{array}{l}\text { NR } \\
\text { NR }\end{array}$ \\
\hline $\begin{array}{l}\text { Akkarathamrongsin } \\
\text { et al. [29], 2014 }\end{array}$ & $\begin{array}{l}\text { Non-RCT } \\
\text { full }\end{array}$ & $\begin{array}{l}\text { Thailand } \\
\text { (Thai) }\end{array}$ & $\begin{array}{l}\text { PEG-IFN } a-2 a \\
\text { PEG-IFN } a-2 b\end{array}$ & $\begin{array}{l}1 \\
6\end{array}$ & $\begin{array}{l}48 \\
48\end{array}$ & $\begin{array}{l}69 \\
42\end{array}$ & $\begin{array}{l}43(62.3) \\
30(71.4)\end{array}$ & $\begin{array}{l}49.0 \pm 10.6 \\
42.0 \pm 8.5\end{array}$ & $\begin{array}{l}47(68.1) \\
33(78.6)\end{array}$ \\
\hline
\end{tabular}

$\mathrm{NR}=$ Not reported. Age is shown as mean $\pm \mathrm{SD}$ or median (range). ${ }^{a}$ Including HCV $-2,3$ and HCV-6.

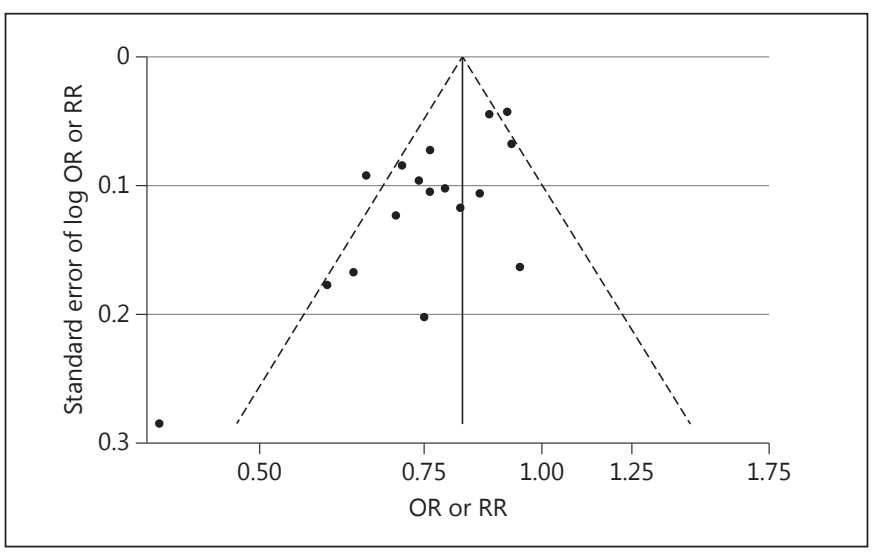

Fig. 2. Funnel plot of the included studies. sessed SVR in rs8099917 TT compared with GT/GG. One study evaluated SVR in rs12979860 CC versus CT/ TT and ss469415590 TT/TT versus non-TT/TT (table 2). With IL28B rs8099917, the SVR rate in TT patients was $96.2 \%$ (50 of 52 ) compared to $62.5 \%$ (5 of 8 ) in patients with the IL28B TG genotype ( $\mathrm{p}=0.014$, OR: 15.0, 95\% CI: 2.0-112.1). Upon analysis of the allelic frequency of major allele $T$ versus minor allele $G$, the same significant association was found ( $\mathrm{p}=0.001, \mathrm{OR}$ : 10.3, 95\% CI: 1.7-45.6). In contrast, for rs 12979860 and ss469415590, no such differences in SVR were observed among patients infected with HCV-6 $(80.6 \%$ in CC vs. $66.7 \%$ in non-CC, $\mathrm{p}=0.593 ; 81.1 \%$ in TT/TT vs. $60 \%$ in non-TT/TT, $\mathrm{p}=0.288$ ). 
Table 2. Overall SVR rates in IL28B (rs8099917 and rs12979860) and IFNL4 (ss4694 15590) patient groups

\begin{tabular}{|c|c|c|c|c|c|c|}
\hline Study name & \multicolumn{2}{|l|}{ SVR, n/total, n } & OR & Lower limit & Upper limit & $\mathrm{p}$ value \\
\hline Study name & \multicolumn{2}{|l|}{ SVR, n/total, n } & OR & Lower limit & Upper limit & $\mathrm{p}$ value \\
\hline Akkarathamrongsin et al. [29], 2014 & $29 / 36$ & $4 / 6$ & 2.07 & 0.31 & 13.68 & 0.450 \\
\hline \multirow[t]{2}{*}{ Study name } & \multicolumn{2}{|l|}{ SVR, n/total, n } & \multirow[t]{2}{*}{ OR } & \multirow[t]{2}{*}{ Lower limit } & \multirow[t]{2}{*}{ Upper limit } & \multirow[t]{2}{*}{$\mathrm{p}$ value } \\
\hline & ss4694 15590-TT/TT & ss4694 15590-non-TT/TT & & & & \\
\hline
\end{tabular}

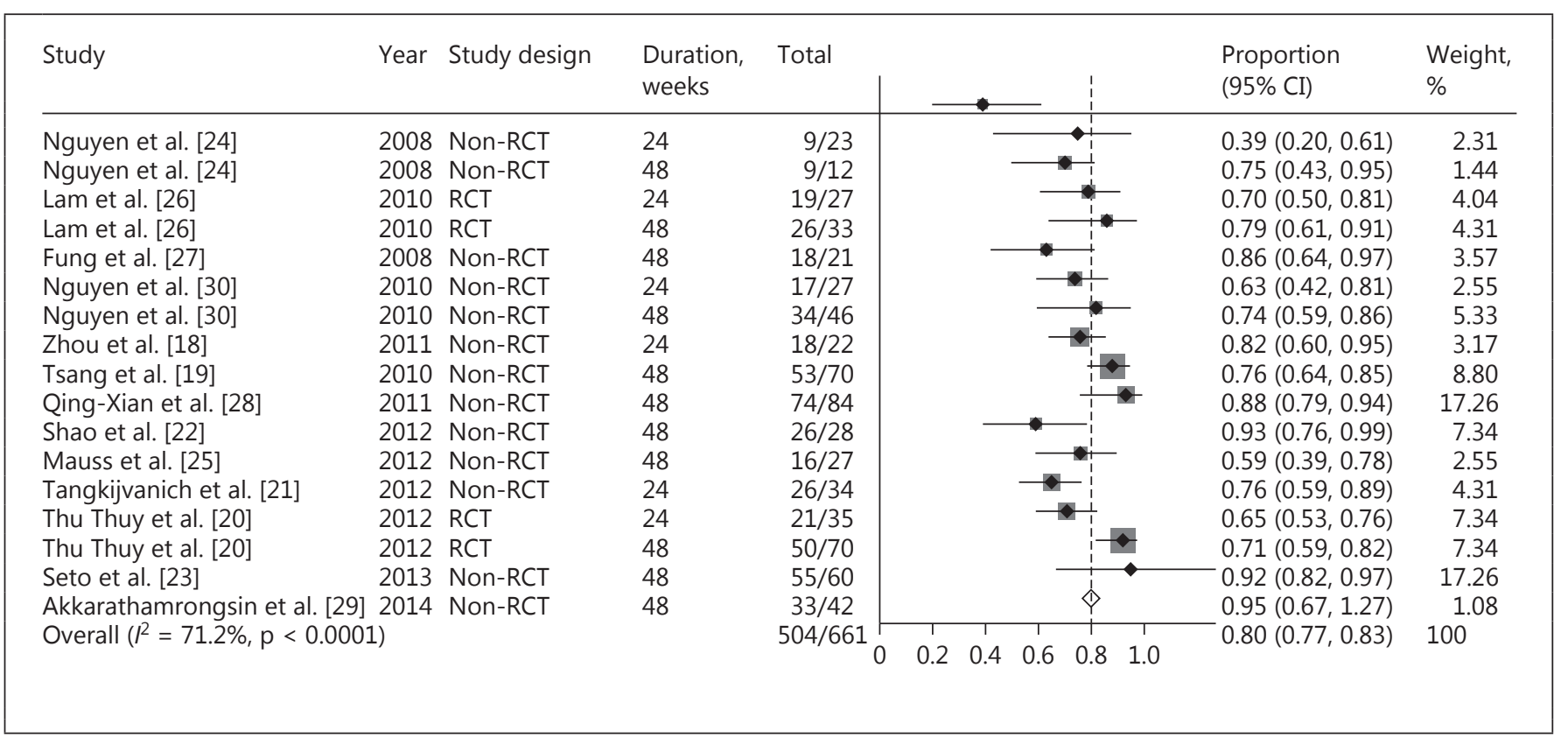

Fig. 3. Overall SVR rate in HCV-6 patients treated with PEG-IFN+RBV.

Mild versus Advanced/Severe Hepatic Fibrosis

A total of 7 studies involving patients with mild and advanced fibrosis were included to evaluate the influence of fibrosis on treatment response [23-27, 29, 30]. Mild and advanced fibrosis were defined as F0-F2 and F3-F4 based on the METAVIR scoring system, respectively. In influence analysis, the SVR rate was 76\% (95\% CI: $0.67-$ 0.84 ) for patients with mild fibrosis and 67\% (95\% CI:
0.61-077) for those with severe fibrosis. Our data indicate that the SVR rate in patients with mild fibrosis is significantly higher than in patients with advanced fibrosis $(\mathrm{p}<$ 0.001).

\section{HCV-6 versus Other Genotypes}

Six trials assessed treatment response in patients infected with HCV-6 compared with those infected with 


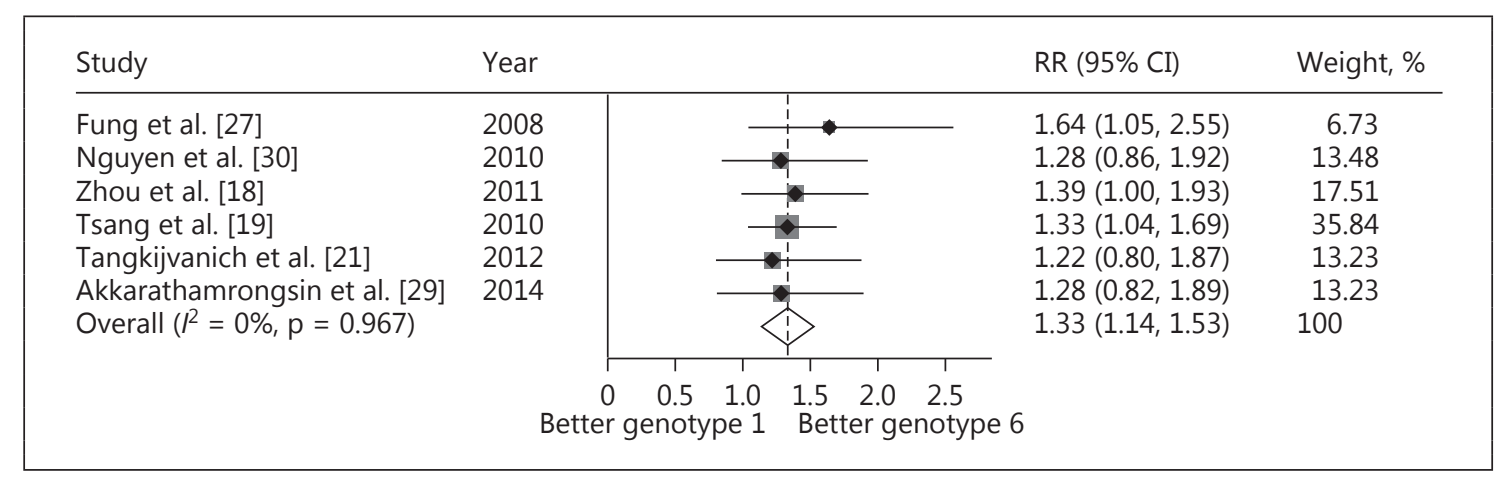

Fig. 4. Meta-analysis of SVR rate in HCV-6 versus HCV-1 patients.

HCV-1 [18, 19, 21, 27, 29, 30]. Among these, 3 were direct comparisons of response to antiviral therapy by HCV -6 versus $\mathrm{HCV}-3$ and/or HCV-2 patients. Patients with HCV-6 displayed significantly better SVR to PEGIFN+RBV combination therapy than those with HCV-1 (80.1 vs. $55.3 \%$ ), with a relative risk of 1.33 (95\% CI: 1.14$1.53, \mathrm{p}=0.904$; fig. 4). Our results are consistent with the majority of previous studies reporting that HCV-6 behaves in a more similar manner to HCV-2 and HCV-3 (SVR rates of 76-80\%) [7-9].

\section{Lower versus Higher Viral Load}

Eight studies explored the association between higher baseline HCV-RNA and treatment outcome. The definition of higher viral load varied across studies, ranging from a threshold of $>200,000 \mathrm{IU} / \mathrm{ml}[19,24],>400,000$ $\mathrm{IU} / \mathrm{ml}[25,27,30],>600,000 \mathrm{IU} / \mathrm{ml}[29]$ to $>800,000 \mathrm{IU} /$ $\mathrm{ml}[21,27]$. The SVR estimate was 73\% (95\% CI: $0.67-$ 0.81 ) in patients with lower viral load and $58 \%$ (95\% CI: $0.45-0.69)$ in those with higher viral load. We observed a similar association between lower baseline viral load and higher SVR rates compared to those with higher viral load (OR: 4.01; 95\% CI: 1.62-5.43, p < 0.001). Significant heterogeneity was evident in our analysis ( $\mathrm{Q}$ statistics = $\left.17.94, \mathrm{p}<0.05 ; I^{2}=71.52\right)$.

Treatment Duration (24 vs. 48 Weeks)

Four studies including 261 patients [149 (57.1\%) treated for 48 weeks and 112 patients (42.9\%) treated for 24 weeks] compared treatment responses in patients administered PEG-IFN+RBV for 48 versus 24 weeks [20, 25, 26, $30]$. We conducted a 2 nd meta-analysis of these studies, which showed that SVR rate at 24 weeks of treatment is significantly lower than that at 48 weeks. Pooled SVR rates were $67 \%$ for 24 weeks (95\% CI: $0.61-0.74 ; \mathrm{p}=0.038$; $I^{2}=57.6 \%$; fig. 5) and 84\% for 48 weeks (95\% CI: 0.80 $0.87 ; \mathrm{p}=0.006 ; I^{2}=59.7 \%$; fig. 6$)$. However, the risk difference was $14 \%$ (95\% CI: -0.25 to -0.02 ).

\section{Discussion}

Although direct-acting antiviral agents have recently been approved for the treatment of chronic HCV infection, PEG-IFN+RBV combination therapy remains appropriate for $\mathrm{HCV}-6$, since the relevant data obtained are insufficient to make general recommendations [32, 33] and not available in most countries in Southeast Asia [3]. Except for a previous study about HCV-4 [11], this is the first systematic review and meta-analysis to evaluate the influence of host and viral factors in patients with chronic HCV-6 treated with PEG-IFN+RBV. In our analysis, which included 14 studies comprising a total of $819 \mathrm{HCV}$ 6 patients treated with PEG-IFN+RBV, the pooled SVR rate was $79.8 \%$ (95\% CI: $0.77-0.83$ ). No publication bias was found. Only 1 earlier study performed a meta-analysis of HCV-6 patients treated with PEG-IFN+RBV [31]. The pooled SVR rate in this report (75\%) was slightly lower than in our results. However, their study did not include subgroup analysis of host and viral factors on SVR, while our investigation incorporated recent studies with a large number of patients and evaluated the influence of host and viral factors on SVR rates in HCV-6 patients. Differences in SVR rates between non-RCT and RCT were evident, with a significantly higher response in nonRCTs $(\mathrm{p}=0.032)$.

The optimal duration of PEG-IFN+RBV therapy in HCV-6 patients depends on several factors and is yet to 


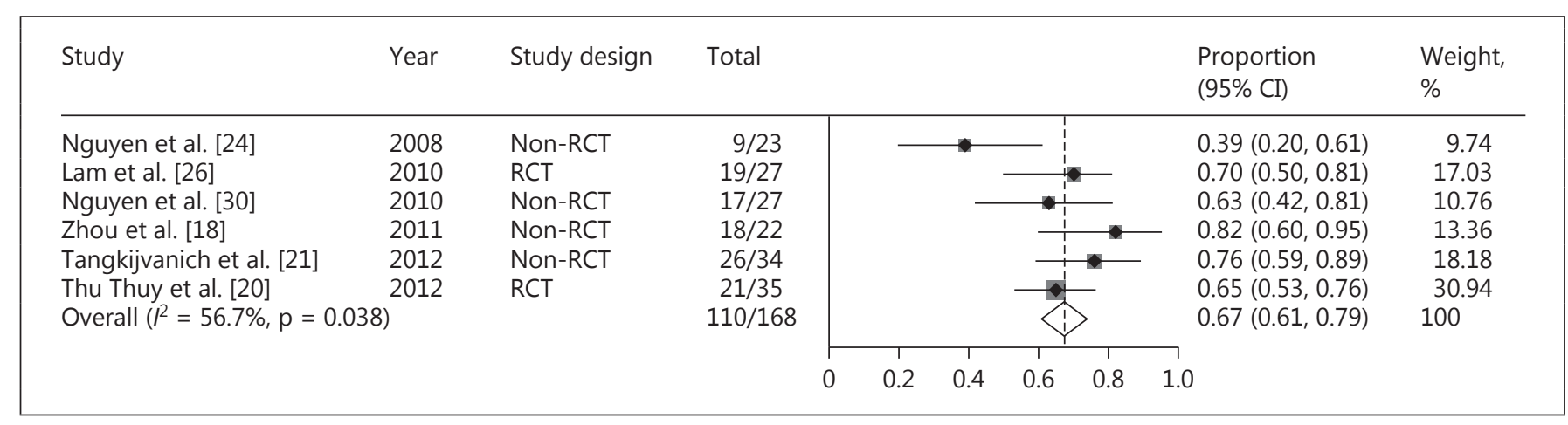

Fig. 5. Overall SVR rate in HCV-6 patients treated with PEG-IFN+RBV for 24 weeks.

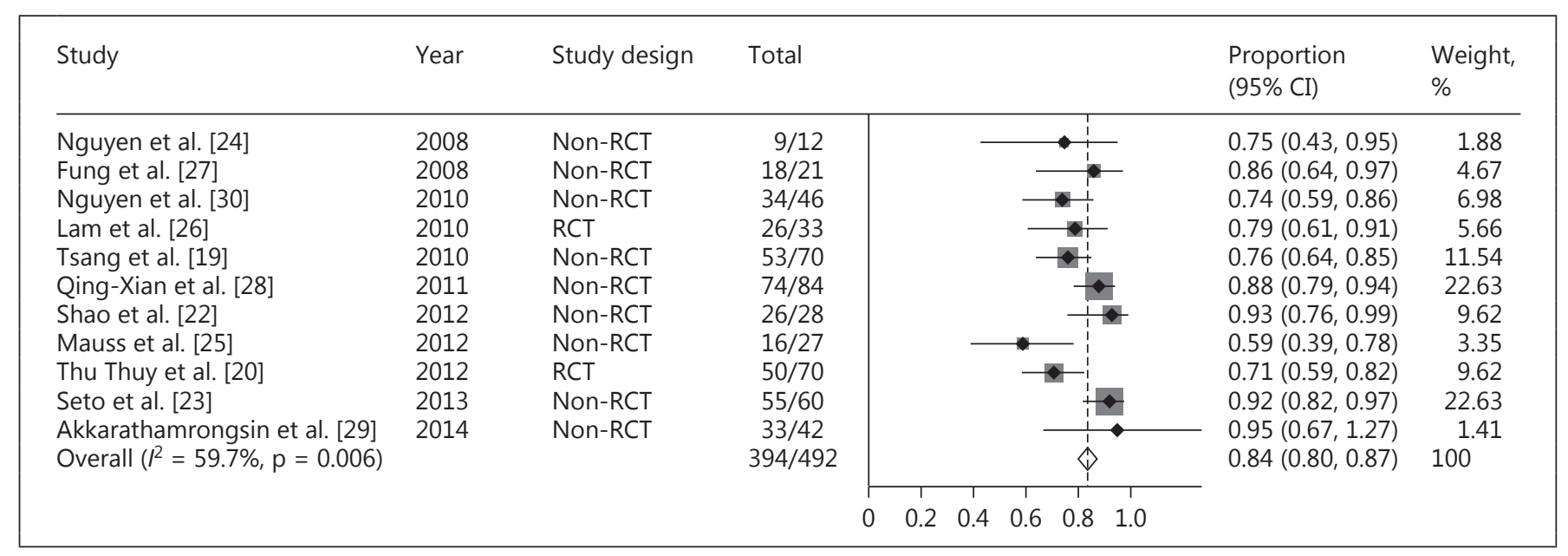

Fig. 6. Overall SVR rate in HCV-6 patients treated with PEG-IFN+RBV for 48 weeks.

be determined. Recent studies reported no significant differences in SVR rates in patients subjected to 48- and 24week regimens. The abbreviated regimen has many advantages, including reducing unnecessary medication exposure, increasing affordability of treatment and maximizing the cost-effectiveness of therapy. Interestingly, in our subgroup analysis of 4 studies $[20,27,32,33]$, the SVR rate at 24 weeks of treatment was significantly lower than that at 48 weeks. Specifically, pooled SVR rates were $67 \%$ for 24 weeks (95\% CI: $0.61-0.74 ; \mathrm{p}=0.038 ; I^{2}=57.6 \%$ ) and $84 \%$ for 48 weeks (95\% CI: $0.80-0.87 ; \mathrm{p}=0.006 ; I^{2}=$ $59.7 \%)$. While 1 retrospective study demonstrated that SVR in HCV-1 and HCV-6 patients is not significantly different [19], the majority of investigations have shown that $\mathrm{HCV}-6$ is closer to HCV-2 and -3 in that patients in these groups respond better to therapy than those with
HCV-1 infection. With regard to the treatment regimen, we did not observe significant differences in SVR rates between patients treated with PEG-IFN $\alpha-2 a$ and PEGIFN $a-2 b(p=0.352)$.

Several host factors (such as age, sex and fibrosis level) play an important role in response to HCV therapy [4, 5, 19]. In our analysis, no significant differences in SVR were found between males and females (OR: 0.81, 95\% CI: $0.71-1.12, p=0.71)$. Notably, the SVR rate in patients with mild fibrosis was markedly higher than that for advanced fibrosis $(76 \%$ for mild fibrosis and $67 \%$ for severe fibrosis; $\mathrm{p}<0.001)$. Baseline viral load has been established as the determinant of treatment response. Lower starting HCV-RNA levels are reported to be associated with higher SVR rates [34]. Consistent with these results, our data showed that lower baseline viral load is signifi- 
cantly related to increased SVR than the higher baseline viral load (OR: 4.01, 95\% CI: 1.62-5.43, p < 0.001). However, larger-scale studies are required to further validate our findings on the effects of gender, fibrosis level and baseline viral load on treatment outcome.

A number of studies have reported that rs8099917 and rs12979860 polymorphisms in IL28B are significantly associated with treatment outcome, especially in $\mathrm{HCV}-1$ patients. Also, a previous meta-analysis on $\mathrm{HCV}-4$ reported an association with SVR with favorable IL28B polymorphisms (rs12979860 CC and rs8099917 TT genotypes) [11]. The 2 studies on IL28B in our subgroup analyses showed a favorable association between SVR and rs8099917 TT genotype versus GT/GG ( $\mathrm{p}=0.014$, OR: 15.0, 95\% CI: 2.0-112.1) [21]. In contrast, the effectiveness of rs12979860 and ss469415590 polymorphisms in predicting treatment response was shown to be attenuated in patients infected with HCV-6 [29]. Our findings do not indicate a sufficiently strong association to support the utility of these polymorphisms in predicting response to therapy in HCV-6 patients.

Although all related studies have been included in our systematic review, the current analysis has several limitations. First, since the number of studies included in this meta-analysis was limited, the overall results were not robust. Furthermore, only abstracts of 3 studies were available and some trials included a few patients, but since all met the inclusion criteria and provided data on the outcome of interest, they were included in our meta-analysis. Second, although the efficacy of PEG-IFN+RBV varies depending on the type of treatment regimen and dose schedule, we were not able to perform sensitivity analyses on these parameters owing to limited data. Despite the above drawbacks, this study provides solid evidence that
PEG-IFN+RBV treatment significantly improves the SVR rate in HCV-6 patients and validates the effects of specific host and virus factors on treatment outcome.

In conclusion, the PEG-IFN+RBV combination is effective in HCV-6 patients, with a pooled SVR rate of $79.8 \%$ in our study. Moreover, treatment outcomes of HCV -6 patients are superior to $\mathrm{HCV}-1$ and comparable to those of HCV-2 and -3. As HCV-1, the optimal treatment duration of HCV- 6 should be 48 weeks, although a shortened treatment duration of 24 weeks could be sufficient. Considering the level of fibrosis in HCV-6 patients may significantly benefit from the recently FDAapproved triple therapies, where available. Gender and type of PEG-IFN did not affect SVR rates. In addition, IL28B and IFNL4 polymorphisms are not significantly associated with treatment outcome in HCV-6 patients.

\section{Acknowledgments}

We would like to express our gratitude to the entire staff of the Center of Excellence in Clinical Virology. This work was supported by the National Research University Project, Office of Higher Education Commission (WCU001-HR-57, WCU007-HR-57 and WCU-58-006-HR), the National Research Council of Thailand, the Research Chair Grant from the National Science and Technology Development Agency, the Chulalongkorn University Centenary Academic Development Project (CU56-HR01), the Ratchadaphiseksomphot Endowment Fund of the Chulalongkorn University (RES560530093), the Outstanding Professor of Thailand Research Fund (DPG5480002), the Siam Cement Group and MK Restaurant Company Limited, the Rachadapisek Sompote Fund of Chulalongkorn University for postdoctoral fellowship to Rujipat Wasitthankasem, the Faculty of Medicine at the Chulalongkorn University and Hospital and the Thai Red Cross Society. The funders had no role in the study design, data collection and analysis, decision to publish or preparation of the paper.

\section{References}

1 Lavanchy D: Evolving epidemiology of hepatitis C virus. Clin Microbiol Infect 2011;17: 107-115.

2 Kim WR: The burden of hepatitis $\mathrm{C}$ in the United States. Hepatology 2002;36:S30-S34.

3 Thong VD, Akkarathamrongsin S, Poovorawan $\mathrm{K}$, Tangkijvanich $\mathrm{P}$, Poovorawan Y: Hepatitis $C$ virus genotype 6: virology, epidemiology, genetic variation and clinical implication. World J Gastroenterol 2014;20:29272940.
4 Fried MW, Shiffman ML, Reddy KR, Smith C, Marinos G, Goncales FL Jr, Häussinger D, Diago M, Carosi G, Dhumeaux D, Craxi A, Lin A, Hoffman J, Yu J: Peginterferon alfa-2a plus ribavirin for chronic hepatitis $\mathrm{C}$ virus infection. N Engl J Med 2002;347:975-982.

5 Manns MP, McHutchison JG, Gordon SC, Rustgi VK, Shiffman M, Reindollar R, Goodman ZD, Koury K, Ling M, Albrecht JK: Peginterferon alfa- $2 b$ plus ribavirin compared with interferon alfa-2b plus ribavirin for initial treatment of chronic hepatitis C: a randomised trial. Lancet 2001;358: 958-965.
6 Chevaliez S, Pawlotsky JM: Hepatitis C virus: virology, diagnosis and management of antiviral therapy. World J Gastroenterol 2007;13: 2461-2466.

7 Nguyen MH, Keeffe EB: Prevalence and treatment of hepatitis $C$ virus genotypes 4,5 , and 6. Clin Gastroenterol Hepatol 2005;3:S97S101.

8 Nguyen NH, VuTien P, Garcia RT, Trinh $\mathrm{H}$, Nguyen $\mathrm{H}$, Nguyen $\mathrm{K}$, Levitt B, Nguyen $\mathrm{MH}$ : Response to pegylated interferon and ribavirin in Asian American patients with chronic hepatitis $C$ genotypes 1 versus $2 / 3$ vs 6 . J Viral Hepat 2010;17:691-697. 
9 Yuen MF, Lai CL: Response to combined interferon and ribavirin is better in patients infected with hepatitis $C$ virus genotype 6 than genotype 1 in Hong Kong. Intervirology 2006; 49:96-98.

10 Rapposelli D: Highlights from the Annual Meeting of the AASLD. Gastroenterol Hepatol (NY) 2014;10:194-195.

11 Yee BE, Nguyen NH, Zhang B, Vutien P, Wong CR, Lutchman GA, Nguyen MH: Meta-analysis: influence of host and viral factors in patients with chronic hepatitis $\mathrm{C}$ genotype 4 treated with pegylated interferon and ribavirin. Eur J Gastroenterol Hepatol 2014;26: 1189-1201.

12 Moher D, Liberati A, Tetzlaff J, Altman DG; PRISMA Group: Preferred reporting items for systematic reviews and meta-analyses: the PRISMA statement. Ann Intern Med 2009; 151:264-269.

13 Higgins JPT, Green S: Cochrane Collaboration: Cochrane Handbook for Systematic Reviews of Interventions. Chichester/Hoboken, Wiley/Blackwell, 2008, pp xxi, 649.

14 Juul S: An Introduction to Stata for Health Researchers, ed 2. College Station, Stata, 2008, pp xx, 361.

15 Kohler U, Kreuter F: Data Analysis Using Stata, ed 2. College Station, Stata, 2009, pp xxv, 388.

16 Chaimani A, Higgins JP, Mavridis D, Spyridonos P, Salanti G: Graphical tools for network meta-analysis in STATA. PLoS One 2013;8:e76654.

17 Qing-Xian C, Zhixin Z, Lin C, Min X, Min W, Mingshou H: Shortened treatment duration in treatment-naive genotype 6 chronic hepatitis $\mathrm{C}$ patients with rapid virological response: a randomized controlled trial (abstract 1855). Hepatology 2013;58:1098.

18 Zhou YQ, Wang XH, Hong GH, Zhu Y, Zhang XQ, Hu YJ, Mao Q: Twenty-four weeks of pegylated interferon plus ribavirin effectively treat patients with HCV genotype 6a. J Viral Hepat 2011;18:595-600.
19 Tsang OT, Zee JS, Chan JM, Li RS, Kan YM, Li FT, Lo FH, Chow DA, Cheung KW, Chan $\mathrm{KH}$, Yeung YW, Ng FH, Li MK, Kwan WK, Lai TS: Chronic hepatitis $C$ genotype 6 responds better to pegylated interferon and ribavirin combination therapy than genotype 1 . J Gastroenterol Hepatol 2010;25:766-771.

20 Thu Thuy PT, Bunchorntavakul C, Tan Dat H, Rajender Reddy K: A randomized trial of 48 versus 24 weeks of combination pegylated interferon and ribavirin therapy in genotype 6 chronic hepatitis C. J Hepatol 2012;56: 1012-1018.

21 Tangkijvanich P, Komolmit P, Mahachai V, Poovorawan K, Akkarathamrongsin S, Poovorawan Y: Response-guided therapy for patients with hepatitis $C$ virus genotype 6 infection: a pilot study. J Viral Hepat 2012;19:423430.

22 Shao X, Zhao Z, Cai Q, Zhang X, Gao Z: The dynamic analysis of the Th1/Th2 ratio during the interferon alpha/ribavirin combination therapy for $\mathrm{HCV}$ genotype 6 infected patients. J Hepatol 2012;56:S66-S67.

23 Seto WK, Tsang OTY, Liu K, Chan JMC, Wong DKH, Fung J: Role of IL28B and inosine triphosphatase polymorphisms in the treatment of chronic hepatitis $\mathrm{C}$ virus genotype 6 infection. J Viral Hepat 2013;20:470477.

24 Nguyen MH, Trinh HN, Garcia R, Nguyen G, Lam KD, Keeffe EB: Higher rate of sustained virologic response in chronic hepatitis $\mathrm{C}$ genotype 6 treated with 48 weeks versus 24 weeks of peginterferon plus ribavirin. Am J Gastroenterol 2008;103:1131-1135.

25 Mauss S, Berger F, Vogel M, Pfeiffer-Vornkahl $\mathrm{H}$, Alshuth U, Rockstroh JK, Niederau C, Hüppe D: Treatment results of chronic hepatitis $C$ genotype 5 and 6 infections in Germany. Z Gastroenterol 2012;50:441-444.

26 Lam KD, Trinh HN, Do ST, Nguyen TT, Garcia RT, Nguyen T, Phan QQ, Nguyen HA, Nguyen KK, Nguyen LH, Nguyen MH: Randomized controlled trial of pegylated interferon-alfa $2 \mathrm{a}$ and ribavirin in treatment-naive chronic hepatitis $\mathrm{C}$ genotype 6. Hepatology 2010;52:1573-1580.
27 Fung J, Lai CL, Hung I, Young J, Cheng C, Wong D, Yuen MF: Chronic hepatitis $C$ virus genotype 6 infection: response to pegylated interferon and ribavirin. J Infect Dis 2008; 198:808-812.

28 Qing-Xian C, Zhixin Z, XiaoHong Z, Gao Z, Lin C, Chunxia H: The high IL-28B CC genotype contribute to the good response of chronic hepatitis $\mathrm{C}$ genotype 6 in China (abstract 993). Hepatology 2011;54:829A.

29 Akkarathamrongsin S, Thong VD, Payungporn S, Poovorawan K, Prapunwattana P, Poovorawan Y, Tangkijvanich P: IFNL3 (IL28B) and IFNL4 polymorphisms are associated with treatment response in Thai patients infected with HCV genotype 1, but not with genotypes 3 and 6. J Med Virol 2014;86: 1482-1490.

30 Nguyen NH, Vutien P, Trinh HN, Garcia RT, Nguyen LH, Nguyen HA, Nguyen KK, Nguyen $\mathrm{MH}$ : Risk factors, genotype 6 prevalence, and clinical characteristics of chronic hepatitis C in Southeast Asian Americans. Hepatol Int 2010;4:523-529.

31 Wang X, Liu F, Wei F, Ren H, Hu H: Efficacy and safety of pegylated interferon plus ribavirin therapy for chronic hepatitis $\mathrm{C}$ genotype 6: a meta-analysis. PLoS One 2014;9:e100128.

32 Lenz O, Vijgen L, Berke JM, Cummings MD, Fevery B, Peeters M, De Smedt G, Moreno C, Picchio G: Virologic response and characterisation of HCV genotype 2-6 in patients receiving TMC435 monotherapy (study TMC435-C202). J Hepatol 2013;58:445-451.

33 Lawitz E, Gane EJ: Sofosbuvir for previously untreated chronic hepatitis C infection. N Engl J Med 2013;369:678-679.

34 Ghany MG, Strader DB, Thomas DL, Seeff LB; American Association for the Study of Liver Diseases: Diagnosis, management, and treatment of hepatitis C: an update. Hepatology 2009;49:1335-1374. 